E. Anna Claydon

\title{
National Identity, the GPO Film Unit and their Music
}

The GPO films, seminal as they were in helping to construct the British social realist movement, are as much remembered for their sound worlds as their visual properties. Whether it is the crackling audio of the ensembles who played, or the (to our ears) richly evocative accents of the narrators, or the adventurous musical soundtracks, the sound worlds of the Empire Marketing Board, GPO and Crown Film Units are utterly textural and utterly of their time and place. This timbre is largely the effect of Alberto Calvancanti's aesthetic, but it is also a reflection of the range of composers and filmmakers employed by the Unit. In this chapter, I shall focus upon the way in which Benjamin Britten and W. H. Auden's sonic collage in Night Mail created and reinforced concepts of national identity and place and how the use of sound in Humphrey Jennings' Spare Time established a semiotic musical sense of British identity by engaging with popular forms, a mode which he would later develop in Listen to Britain. These are films which are much discussed and much loved, but for that same reason, it is worthwhile to step back, to distance ourselves somewhat and to re-examine the elements we can take for granted: what we hear that we know too well. Consequently, this chapter situates the development of a documentary 'national soundtrack' within it specific cultural and artistic contexts.

Benjamin Britten was the Musical Director for the Unit from September 1935 until late 1936. He had previously been part of the BBC team which shaped the soundscapes of the pioneering radio 'features' in 1934 and $1935 .{ }^{1}$ Britten's earlier 
work and collaboration with the mass media echoes Jennings' work outside of the medium of film. Britten's experience of working in radio was indeed one of the reasons behind his appointment to the Unit. He was the key composer for the important Coal Face, which Basil Wright described as 'part of a series of experiments with sound on which our group has been for some time engaged: and it was in a sense the test-tube form which the formula for Night Mail was created. ${ }^{2}$

Coal Face can be placed securely within a tradition of British moving picture documents, from actualités such as Day in the Life of a Coal Miner (1910) to the Mitchell and Kenyon coal pit films. To represent the miner was already part of the iconography of British working-class national identity and had a place within British cinema innovation, revealing the humanity of Britain's most dangerous job outside the military. To place the mining story within a contemporary aesthetic prevented it from becoming nostalgic and give it cultural currency within modernism. At the time, analysing the new documentary movement, Kurt London wrote that in Coal Face:

\footnotetext{
Britten formed a unity of music, words spoken in chorus, and stylised noises. It is astonishing to observe how, with the most scanty material, using only a piano and a speaking chorus, he can make us dispense gladly with realistic sounds...The rhythms of life are hard: hard likewise is the music and its interweaving with the speaking choruses. The general atmosphere of the film is dark, and its music neither makes it brighter nor does it underline the shadows superfluously. In a word, the power-ratio between picture and music is always most ideally balanced. ${ }^{3}$
}

The majority of Night Mail, in contrast to Coal Face (with its use of inter-titles and overt narrative structuring) is in a more observational mode, with three narrators 
shaping the journey of the overnight postal special from Euston to Glasgow. Its many sounds are emphasised and reinforced through editing and through images which contain a specific movement (for example, a switch being moved) which are synchronised with an overlaid sound. The presence of music, however, is limited to the opening titles and the final part of the film, accompanying Auden's poem. Considering that most audiences remember Night Mail because of the music and the rhythm of the poem, it is interesting that the film is in fact largely made up of diegetic sounds (sounds heard on the soundtrack which are linked to objects or actions seen on screen, in contrast to superimposed music) which many have forgotten, emphasising the power Britten and Auden had on the reputation of the film. Mitchell records that, for the film, Britten was given his largest recording orchestra to date: a flute, oboe, bassoon, trumpet, harp, violin, viola, cello and double bass. His 'percussion' were compressed air in a canister, sandpaper on slate, a small trolley on a short piece of railing, booms for clanking sounds, a hand-cranked camera for metallic mechanical motion sounds, a hammer on a boom or conduit, a siren and a bag of coal for throwing down a shaft. ${ }^{4}$ This meant that the soundscape Britten was creating was performing two tasks: a musical one and a sonic imitation of the sounds of industry. The sound world of industry entered the musical score and led Britten to radically rethink the meaning of programmatic scoring.

The ensemble performing in Night Mail represents all the basic aspects of a large orchestra. This meant that Britten could use the instruments in a short-hand form that the audience would recognise as coherent with classical music and the film music they heard in fictional films. Thus, the trumpet functions as herald and horn, whilst the strings, with their flexibility of sound, work traditionally, playing chords and 
melody and also using extended techniques alongside the atypical percussion section. The orchestration was clearly designed to work in partnership with the poem written by Auden and viewers of the film should think of the music and voice working together as a complete composition, with the spoken voice as a recitative. The most significant problem for Britten, however, seems to have been layering the two together in post-production and Britten's diary for 15 January 1936 notes:

There is too much to be spoken in a single breath by one voice (and it is essential to keep the same voice \& to have no breaks) so we have to record separately - me, having to conduct from an improvised visual metronome flashes on the screen - a very difficult job! Legg speaks the stuff splendidly tho' ${ }^{5}$

As such, the poem was thought of by Britten entirely in musical terms, substantiating a musical approach to Legg's narration as recitative. What recitative means musically is a carefully pitched but mainly unsung solo which is, typically, rhythmically in line with conversational speech. In opera, the recitative creates the link between dramatic action and full song or aria. In terms of national identity, the even voice Legg presents is symbolically very important because it signifies unity and an even-temperedness to the audience. Yes, it is a middle-class voice, but it is also a voice designed to make the work performed in the film something which crosses the landscape without accent: it reinforces the national identity at the same time as the film shows the regions as united by the rail (and the mail). As Dai Vaughan noted in 1983: the film 'articulates a meaning of 'work'... Night Mail does, if nothing else, give form to a myth oppositional to that of the Great Artist. ${ }^{6}$ The content of the poem also reiterates this through reference to all kinds of people, and 
as such the film both develops some of the methods used by the Empire Marketing Board and predicts some of the methods for communicating national pride used by Cavalcanti in Went the Day Well? (1942) and David Lean in This Happy Breed (1944).

That Night Mail sought to present the nation, and to show audiences parts of the country they would not have seen, can be witnessed in the GPO morality tale of 'address your letter correctly' and the pride in the letters posted in Bletchley only 30 minutes before the train collects them, but there are errors which also belie the south-centric understanding of the line above Crewe by placing Warrington and Wigan in the wrong order. Nevertheless, this surprising error in the film ultimately adds to the film's charm, emphasising the poetry of the narration above the documentary reality. In conjunction with the performance styles of the musical ensemble and the 'acting' railway men, this geographical mistake lends Night Mail an amateurism (in both the sense of something not perfectly polished and in the sense of something coming from love of the subject) which is an important aspect of a number of the GPO and Crown Film unit films because it makes the art form and its subject matter more accessible and 'of the people'. This is a spirit which is also fundamental to Humphrey Jennings' films and which helps to take the work of the GPO Film Unit from being the output of an artistic elite to something more in tune with national identit(ies) and with people. Spare Time, however, the first of Jennings' films in which this comparable spirit is particular notable, is a film about the country beyond London and thus has a completely different tone in its expression of region: one of the people within industry, not the industry within people. 
The aural filmic predecessor to 'This is the night mail, crossing the border' can be heard in the train sequences of Cavalcanti's Pett and Pott: A Fairy Tale of the Suburbs. Helping to demonstrate that Cavalcanti's concept was later developed in Night Mail, Pat Jackson, writing in 1999, also saw signs of the film's best known rhythmic content in Basil Wright's early draft script for Pett and Pott:

\footnotetext{
Basil's equivalent [of Auden's poem to come], scribbled in one of those large Post Office notebooks, read roughly as follows: 'Over close shots of the locomotive funnel belching smoke as its struggles up the Beattock gradient, the puffs gets slower and greyer and maybe we could lay over a voice saying, "I think I can, I think I can". ,7
}

Added to this, Pett and Pott was reputedly an 'evolution' of an idea from Jennings, and elements of George Orwell's critique of suburban life in Keep the Aspidistra Flying (published two years later in 1936). This confirms that Pett and Pott and Night Mail are linked in ways which emphasise that Jennings, Auden, Britten, Wright and Cavalcanti's approaches to sound design were always framed with the wit of the 1930s social journalist and not just the eye of the social realist. These elements, these connections amongst the writers, composers and filmmakers of the 1930s, should accurately be seen as part of the way in which a debate about national identity was taking place: what was the modern, the technological British national identity, what did it look like, sound like and feel like? These were modernist questions which would be placed in a kind of stasis during the Second World War.

The presence of modernist answers in GPO films shows that a route was being carved out to a concrete understanding of what contemporary British identity was. 
This was done by representing Britain as a series of spaces. Space to live (modern housing), space to work (in the office, on the trains at the post office - all in the service of something larger), space to identify with (regional identities coming through in the 1930s cinema), space to aspire to, and, importantly, spaces in which to hear and be heard. It is all too easy for the post-Second World War generation to forget that Britain was an aural media nation in the 1930s and 1940s. It is all too easy to forget that the sonic spaces of the radio mapped onto and into the daily lives of people and helped to contribute to the mid-century national identity. That is why, when Jennings later made Listen to Britain in 1942, hearing the sounds of Britain was far more important than seeing the stars of the day for constructing national pride. The sounds of Britain make it more concrete, more real than its imagery alone.

In his later music, the creation of sonic spaces is something with which Benjamin Britten became particularly associated (consider, for example the opening of Billy Budd (1951) with its evocation of the Suffolk coast) but these elements are evident in his music for the GPO Film Unit too and establish Britten as an explorer of musique concrète and avant-garde concepts of musical noise. Musique concrète means a form of electro-accoustic music in which sounds produced accoustically are processed electronically to produce a semiotically interesting and complex musical sound (in the sense of John Cage's 'organised noise'). Britten's experiments in Night Mail and Walter Leigh's in Song of Ceylon further demonstrate the cutting edge work in the Unit. They precede the accepted innovators of musique concrète (such as Pierre Schaffer who worked with the director Jean Rouch) in the 1950s. 
The use of objects as instruments (the boom, the hammer, etc...) also link Britten and Cage more explicitly in terms of expressionism in the contemporary music of the 1930s and 1940s. However, the pre-existing train-rhythm provided Britten and Auden with something conventional to work with. This enabled the avant-garde to be couched within the familiar and made Britten's music almost folksy, using a set of rhythms and simple methods of composition which audiences recognised from nursery rhymes and programmatic music of the nineteenth century. A certain folksiness is absolutely central to Humphrey Jennings' Spare Time, which, as I noted earlier, utilised the spirit of the amateur, although here more literally through its celebration of what the working people of 1930s Britain do outside work. As lan Aitken wrote in 1997:

His Spare Time (1939) and Listen to Britain (1941) remain impressive, marked by a lyrical humanism and a sensitivity to the ordinary which stands out from the often stereotyped representation of working-class people found in some of the films made by the documentary movement. ${ }^{8}$

Lyrical humanism means, for Spare Time, the difference between people as cogs in a machine and people as sensual beings and as the narration, provided by Laurie Lee, says: 'Spare Time is a time when we have a chance to do what we like, a chance to be most ourselves.' Significantly, the audience is presented with people that are being signalled as 'ourselves': they are the everymen and women of four urban British peoples. For the steel industry, The Steel, Peech and Tozer Pheonix Works Band (Sheffield) represent the working men; for the largely female and young cotton workers, The Manchester Victorians Carnival Band dressed in satins and playing the kazoo represent those new to the workforce but with history behind them; 
for the minors of Britain, the Handel Male Voice Choir of Pontypridd sing out; and for the workers of Bolton communities - crossing over between the cotton and coal industries, people are seen walking dogs, playing sports and enjoying a pint of beer in the pub. Basil Wright, however, had reservations about the way in which the people were represented, believing that it had a 'patronising, sometimes almost sneering attitude towards the efforts of low-income groups. ${ }^{19}$ This, I would argue, is an unfair judgement, because Jennings presents each group as people 'we' could know through small gestures such as helping the pianist at the Handel Male Voice Choir to take off her coat whilst still playing. The humour is not to be laughed at but to be laughed with.

Constructed from a combination of diegetic and non-diegetic sound but with the diegetic prioritised, the sound of the film provides an immediacy which echoes the theme of the film. This immediacy arises in part from the kind of diegetic sounds that the audience hears: we do not just hear a piano, we hear an out-of-tune piano; we do not just hear a band, we hear a band of handmade kazoos played like trumpets by a troupe in handmade costumes; we do not just hear and see a family preparing for tea, we hear the banter between a family which has its own language. These sounds are discovered by the film, they are observed in the spirit of the Mass Observation movement of which Jennings was a co-founder. These sounds are found within the film and encountered within the spaces between the narration.

In all of his musical films, Jennings was interested in found musical objects (of sorts) - that is, music found in the environment rather than music imposed upon the film. Where Spare Time is a little different is that Handel's 'Firework Music' is used to 
herald and close the film. The function of this is twofold: firstly, using music written for the state means that Jennings signalled that the music within the film is of equal status; and secondly, using a recording of music associated with royalty identifies the people with their rulers and democratises the conceptualisation of nation. Given that the film was reportedly commissioned for the New York World Trade Fair, this democratisation is important. The presentation of everyday music-making as informal and dynamic indicates Jennings' identification with informal popular culture (even regarding the classical genres) rather than formal concert culture (which he later represented in Listen to Britain).

It is also important in examining the sound world which Jennings' is presenting to consider the role of Laurie Lee's narration as part of the way in which the film seeks to present contemporary Britain to an external (American) audience. Lee (best known for his novel Cider with Rosie, published twenty years later in 1959 but set in the 1920s) is a conventional received pronunciation English-accented man who initially sounds like he is presenting the leisure hours of the British worker as a travelogue with a distinct detachment: that is precisely his function. Spare Time is not just a travelogue for American audiences, it is a travelogue for British audiences too. When George Orwell published The Road to Wigan Pier in 1937, he was demonstrating an interest in industry from within the southern middle classes and performing a role which was both journalistic and performative: giving the working classes an authentic, albeit mediated, voice. At around the same time, Edgar Anstey, in Housing Problems (1935) was presenting the first vox populi interviews of Londoners in the slums and a little later, in The Stars Look Down (Carol Reed, 1939) and Love on the Dole (John Baxter, 1941), audiences were being faced with the 
social realities of the poor majority. Laurie Lee, therefore, aurally ushers the audience into the spare times of Britain and his voice-over becomes sparse and eventually so insignificant by the time we get to the Coal section of the film that instead of introducing the working patterns (as with steel and cotton), he merely says 'Finally, coal...' The introduction is not necessary any longer. The relationship between text, subjects and audience has shifted and the tempo has altered, as epitomised by one of the most interesting aspects of the presentation of music in Spare Time: the way in which tempo is manipulated, especially with the classical pieces present ('Rule Britannia', performed by the Manchester Victorians Carnival Band, 'Ombra mai fu' from Handel's Xerxes and 'Never was there a shadow', from the Handel Male Voice Choir in Pontrypridd). The impact of this shift in time signatures is both metaphorical and significant because the lengthening of phrases and the addition of notes, the slowing and speeding up of sections become a metaphor for spare time (as in the time within bars, the time signature), for the people finding the time within the framework to make these pieces their own. The manipulation of time is significant for another reason too, because within the context of a film which is trying to communicate something about a modern Britain which is proud of but not tied to its imperial past, the swung rendition of Rule Britannia, more than anything else in the film, evokes a modern Britain, a modern British identity and a modern British pride for the 1930s.

The music used in both Night Mail and Spare Time, then, signifies a democratising of 'high' culture and a raising of status of music and forms previously designated 'low' culture (to use the terms of the period). The music and sound also reinforce and develop a sense of place for different audiences, despite errors contained within 
each which lead to a homogenisation of region in both films. This means that both films reveal something about British national identity for audiences who are new to the films' content (for instance, the train as mechanics of empire and popular culture during leisure time as the soul of nation). Both films signal a sense of the moment. Night Mail draws on the structure of films Grierson admired (the temporally continuous narrative) whilst Spare Time privileges narratives that have long been used to represent Britishness - ultimately presenting a state of the nations narrative in which the brass band, choir and kazoo band evoke a present which is proud of its past.

This national soundtrack, then, is one which sits well alongside the intellectual efforts of the period and establishes a set of concepts which film soundtracks have used in documentary ever since. Sound and music need not simply reinforce action or be 'atmospheric'; they can be part of a commentary and make one not just see again, as the Mass Observation movement aimed to do, but also to listen again.

\section{Notes}

${ }^{1}$ D. Mitchell, Britten and Auden in the Thirties: The Year 1936 (London: Faber \& Faber, 1981), p. 80

2 Basil Wright, 'Britten and Documentary', The Musical Times, 104 (1963), pp. 779-80.

${ }^{3}$ London (1936) Film Music quoted in Huntley (1947) British Film Music in Wiffen, 2003: p. 22

${ }^{4}$ Mitchell, Britten and Auden, p. 82, p.84

5 Mitchell, Britten and Auden, p.84

${ }^{6}$ Dai Vaughan, 'Night Mail', in Kevin MacDonald \& Mark Cousins (eds.), Imagining Reality: The Faber Book of Documentary (London: Faber \& Faber, 1997), p.121

${ }^{7}$ P. A. Jackson, A Retake Please! Night Mail to Western Approaches (Liverpool: Liverpool University Press, 1999), p. 23 


\footnotetext{
${ }^{8}$ Ian Aitken, 'The British Documentary Film Movement' in Robert Murphy (ed.), The British Cinema Book
} (London: BFI, 1997), pp. 63

${ }^{9}$ Basil Wright cited at http://www.screenonline.org.uk/film/id/ 443890/. 